\title{
UPAYA PEMERINTAH DESA \\ MENDORONG PARTISIPASI MASYARAKAT \\ DALAM MEMBANGUN DESA NGAYAU KECAMATAN MUARA BENGKAL KABUPATEN KUTAI TIMUR
}

\author{
M. Kasim Makarno \\ Mohamad Husni \\ Dosen Ilmu Administrasi Negara FISIP Universitas Widya Gama Mahakam Samarinda \\ Suryani \\ Anggota Peneliti Ilmu Administrasi Negara FISIP Universitas Widya Gama Mahakam Samarinda
}

\begin{abstract}
Abtrak
Desa sebagai ujung tombak pembangunan masyarakat perlu untuk terus dikembangkan. Salah satunya dengan meningkatkan partisipasi masyarakat, karena pembangunan tersebut akan dinikmati oleh masyarakat tersebut. Penelitianinibertujuanuntukmemperolehinformasilebihdalammengenai Upaya Pemerintah Desa Mendorong Partisipasi Masyarakat Dalam Membangun Desa Ngayau Kecamatan Muara Bengkal Kabupaten Kutai Timur. Dengan menggunakan penelitian kualitatif deskriptif.
\end{abstract}

Dengan berfokus padaMelakukankegiatan pembinaaan kepadamasyarakat, Melakukan kegiatan pembangunan melibatkan masyarakat,Melakukan kegiatan musrenbang melibatkan masyarakat, Melibatkan masyarakat dalam pelestarian kesenian tradisional. Adapun Faktor pendukung dan sekaligus faktor kekuatan upaya pemerintah Desa mendorong partisipasi masyarakat dalam membangun Desa adalah hal ini disebutkan dalam Undang-undang Nomor 6 Tahun 2014 tentang Desa. DidalammelakukanpembinaanseharusnyapemerintahDesamelibatkanseluruh masyarakat khususnya pemuda agar SDM Desa Ngayau bisa baik dan meningkat. Pelibatan masyarakat didalam pembangunan Desa, pemerintah seharus mensosialisasikan tentang pentingnya pelibatan masyarakat didalam pembangunan desa dengan gotong royong. Keterlibatan masyarakat didalam musawarah perencanaan pembangunan sangat kurang, pemerintah Desa seharusnya memberikan kesempatan masayarakatuntukikut serta dan menyampaikan aspirasinya sendiri. Pemerintah Desa melalui Tokoh Adat harus mensosialisasikanlagi tentang pentingnya mengembangkan dan melestarikan kesenian tradisional.

Kata Kunci: UpayaPemerintahDesa,MendorongPartisipasiMayarakat, Membangun Desa.

\section{Abstract}

The village as spearheading the development of society need to be developed. One of them by increasing community participation, because such development will be enjoyed by the community. This study aims to obtain more information about the efforts of the Government in Promoting Rural Community Participation In Village Building ngayau Muara Bengkal East Kutai Regency. By using descriptive qualitative research.

By focusing on Conducting pembinaaan to the public, Doing activities involving community development, Conducting musrenbang involve the community, involve the community in the preservation of traditional arts. As for the supporting factors and at the same time the power factor of village government efforts to encourage public participation in building this village is mentioned in Law No. 6 of 2014 concerning the village.In doing coaching village government should involve the whole community, especially the youth so that human resources can ngayau village well and increased. Community involvement in the development of the village, socialize seharus government about the importance of community involvement in rural development with mutual cooperation. Community involvement in development planning is lacking, the village government should give the community an opportunity to participate and express their own aspirations. The village 
government through traditional figure should socialize more about the importance of developing and preserving traditional arts.

Keywords: Government Efforts Village, Encourage Public Participation, Village Building

\section{Latar Belakang}

Sebagai upaya untuk menghadapi berbagai tantangan dan perkembangan keadaan , baik didalam maupun di luar Negeri, Negara Kesatuan Republik Indonesia (NKRI) mengadakan perubahan yang mendasar dengan memeberikan kewenangan yang luas, nyata dan bertanggung jawab kepada daerah secara proposional, yang diwujutkan dengan peraturanperaturan, pembagian dan pemanfaatan sumber daya nasional, serta perimbangan keuangan pusat dan daerah, sesuai dengan prinsip-prinsip demokrasi, peran serta masyarakat, pemerataan dan keadilan serta potensi dan keanekaragaman daerah.

Ini sesuai Undang-undang No 23 Tahun 2014 Tentang Pemerintah Daerah "Dalam Undangundang ini yang dimaksud dengan Pemerintah daerah adalah penyelenggaraan urusan pemerintah oleh pemerintah daerah dan dewan perwakilan rakyat daerah menurut asas otonomi dan tugas pembantu dengan prinsip otonomi seluas-luasnya dalam sistem dan prinsip Negara Kesatuan Republik Indonesia, sebangaimana yang dimaksud dalam Undangundang 1945." Pemerintah Daerah adalah kepala daerah sebagai unsur penyelenggara Pemerintahan Daerah yang memimpin pelaksanaan urusan pemerintahan yang menjadi kewenangan daerah otonom Dewan Perwakilan Rakyat Daerah yang selanjutnya disingkat DPRD adalah lembaga perwakilan rakyat daerah yang berkedudukan sebagai unsur penyelenggara Pemerintahan Daerah. Urusan Pemerintahan adalah kekuasaan pemerintahan yang menjadi kewenangan Presiden yang pelaksanaannya dilakukan oleh kementerian negara dan penyelenggaraPemerintahan Daerah untuk melindungi, melayani, memberdayakan, dan menyejahterakan masyarakat Otonomi Daerah adalah hak, wewenang, dan kewajiban daerah otonom untuk mengatur dan mengurus sendiri Urusan Pemerintahan dan kepentingan masyarakat setempat dalam sistem Negara Kesatuan Republik Indonesia. Asas Otonomi adalah prinsip dasar penyelenggaraan Pemerintahan Daerah berdasarkan Otonomi Daerah Desentralisasi adalah penyerahan Urusan Pemerintahan oleh Pemerintah Pusat kepada daerah otonom berdasarkan Asas Otonom Dekonsentrasi adalah pelimpahan sebagian Urusan Pemerintahan yang menjadi kewenangan Pemerintah Pusat kepada gubernur sebagai wakil Pemerintah Pusat, kepada instansi vertikal di wilayah tertentu, dan/atau kepada gubernur dan bupati/wali kota sebagai penanggung jawab urusan pemerintahan umum Instansi Vertikal adalah perangkat kementerian dan/atau lembaga pemerintah nonkementerian yang mengurus Urusan Pemerintahan yang tidak diserahkan kepada daerah otonom dalam wilayah tertentu dalam rangka pembagunan untuk daerah.

Didalam pembangunan masih terdapat permasalahan yang sangat relevan dibahas, alasannya. Pertama, dalam dua dasawarsa terakhir, perkembangan hanya berkecimpung di daerah perkotaan sementara secara umum Negara kita Indonesia masih didominasi oleh pedesaan. Kedua, kendati pada masa pemerintahan Orde Baru telah mencanangkan berbagai upaya kebijaksanaan dan program pembangunan pedesaan, tetapi secara riil dapat kita lihat bahwa kondisi social ekonomi masyarakat pedesaan masih sangat jauh dari yang diharapkan (memprihatinkan) Oleh karena itu, pemberdayaan Masyarakat Desa sangat perlu diperhatikan oleh Pemerintah dan perkembangan pembangunan masyarakatpedesaan tidak hanya semata-mata pada sector pertanian, distribusi barang dan jasa tetapi lebih kepada kegiatan yang menyentuh pemenuhan berbagai macam kebutuhan segenap anggota masyarakat sehingga mereka lebih bisa mandiri, percaya diri, tidak bergantung dan terlepas dari belenggu yang membuat hidup sengsara.

Pembangunan juga perlu diarahkan untuk merubah kehidupan masyarakat menjadi lebih baik sehingga dapat tercapai tujuan dari ruang lingkup pembangunan pedesaan yang sangat luas. 
Mengingat pentingnya upaya pemerintah Desa mendorong partisipasi masyarakat dalam membangun Desa, "hal ini tentu saja membuat Pemerintah Desa Ngayau juga tidak ketinggalan untuk mengwujudkannya." Diamana diharapkan pemerintah lebih berperan untuk memotivasi masyarakat, agar masyarakat mau ikut serta berpartisipasi dalam pelaksanaan pembangunan yang ada di Desa Ngayau Kecamatan Muara Bengkal Kabupaten Kutai Timur, adapun beberapa indikasi yang menyebabkan kurangnya upaya pemerintah desa mendorong partisipasi masyarakat dalam membangun desa antara lain, kurang berkualitasnya Kepala Desa dan kurang paham akan perannya sebagai pemimpin, juga banyak masyarakat yang belum tahu dan yang tak mau tahu betapa penting pemberdayaan didalam usaha atau upaya pemerintah mendorong partisipasi masyarakat dalam membangun Desa, masyarakat cenrung tidak mau ikut serta didalam urusan pemerintah dikarnakan kurangnya kepercayaan terhadap pemerintah kondisi demikian membuat sikap apatis yang menguat sehingga bila mereka tidak tahu tentang upaya pemerintah Desa mendorong partisipasi masyarakat dalam membangun desa maka mereka akan tidak terlibat dalam pembagunan yang ada di desa.

Berdasarkan uraian sebagai mana diatas masalah "Upaya Pemerintah Desa mendorong partisipasi masyarakat dalam membangun Desa Ngayau, Kecamatan Muara Bengkal, Kabupaten Kutai Timur." Merupakan salah satu hal yang menarik untuk di kaji dan untuk mendapatkan gambaran yang lebih konkrit mengenai Upaya Pemerintah Desa mendorong partisipasi Masyarakat dalam membangun Desa Ngayau Kecamatan Muara Bengkal Kabupaten Kutai Timur didalam menjalankan fungsi-fungsinya tersebut maka dapat dilakukan melalui penelitian lapangan.

\section{Permasalahan}

Berdasarkan latar belakang yang telah dikemukakan, maka masalah yang dihadapi dirumuskan sebagai berikut:

a. Bagaimana Upaya Penerintah Desa mendorong partisipasi masyarakat dalam membangun Desa Ngayau Kecamatan Muara Bengkal Kabupaten Kutai Timur.

b. Faktor-faktor apa yang mendukung dan menghambat Upaya Pemerintah Desa di mendorong partisipasi masyarakat dalam membangun Desa Ngayau Kecamatan Muara Bengkal Kabupaten Kutai Timur

\section{Tujuan}

Bedasarkan rumusan masalah diatas, adapun tujuan yang ingin dicapai dari penelitian ini adalah untuk mengetahui Upaya Pemerintah Desa mendorong partisipasi Masyarakat dan faktorfaktor penghambat dan pendukung dalam pelaksanaan upaya pemerintah Desa mendorong partisipasi masyarakat dalam membangun Desa Ngayau Kecamatan Muara Bengkal Kabupaten Kutai Timur.

\section{Fokus Penelitian}

Untuk membatasi dan mempertegas dari ruang lingkup serta objek yang diteliti atau untuk memberikan jawaban terhadap rumusan masalah adapun yang menjadi fokus peneliti ini adalah:

a. Melakukan kegiatan pembinaaan kepada masyarakat

b. Melakukan kegiatan pembangunan melibatkan masayarakat

c. Melakukan kegiatan musrenbang melibatkan masyarakat

d. Melibatakan masyarakat dalam pelestarian kesenian tradisional

e. Faktor-faktor Penghambat dan Pendukung Dalam Pelaksanaan Upaya Pemerintah Desa Dalam Mendorong Partisipasi Masyarakat Dalam Pembangunan Desa. 


\section{Kerangka Teori}

\subsection{Pengertian Upaya}

Pengertian Upaya. Menurut Tim Penyusun Departemen Pendidikan Nasional (2008:1787), "upaya adalah usaha, akal atau ikhtiar untuk mencapai suatu maksud, memecahkan persoalan, mencari jalan keluar, dan sebagainya".

Menurut Poerwadarminta (1991 : 574), "Upaya adalah usaha untuk menyampaikan maksud, akal dan ikhtisar. Upaya merupakan segala sesuatu yang bersifat mengusahakan terhadap sesuatu hal supaya dapat lebih berdaya guna dan berhasil guna sesuai dengan maksud, tujuan dan fungsi serta manfaat suatu haltersebut dilaksanakan".Upaya sangat berkaitan erat dengan penggunaan sarana dan prasarana dalam menunjang kegiatan tersebut, agar berhasil maka digunakanlah suatu cara, metode dan alat penunjang yang lain.

Dari beberapa pengertian di atas, maka peneliti dapat menyimpulkan "bahwa pengertian dari upaya adalah suatu kegiatan atau usaha dengan menggunakan segala kekuatan yang ada dalam mengatasi suatu masalah".

\subsection{Pengertian Pemerintah}

Dengan menggunakan pendekatan dari segi bahasa terhadap kata Pemerintah dan Pemerintahan, kedua kata tersebut berasal dari kata "perintah" berarti sesuatu yang harus dilaksanakan. "Di dalam kata "perintah" tersimpul beberapa unsur yang merupakan ciri khasnya, yaitu :1. Adanya keharusan, menunjukkan kewajiban untuk melaksanakan apa yang diperintahkan. 2 Adanya dua pihak, yaitu yang memberi perintah dan yang menerima perintah. 3. Adanya wewenang atau kekuasaan unruk memberi perintah."

Di dalam bahsa Inggris istilah "pemerintahan dan pemerintah tidak memiliki perbedaan yang disebut dengan "government". Istilah ini bersumber dari latin yaitu "gubernauculum" yang berarti kemudi. Kata government dapat bermakna. Melaksanakan wewenang pemerintahan, Cara atau sistem memerintah, Fungsi atau kekuasaan untuk memreintah, Wilayah atau Negara yang diperintah, Badan yang terdiri dari orang-orang yang melaksanakan wewenang dan administrasi hukum dalam suatu Negara."

Menurut Moh. Kusnardi dan Bintan R. Saragih (2008 :122), "Pemerintah adalah alat bagi Negara dalam menyelenggarakan segala kepentingan rakyatnya dan merupakan alat juga, dalam mewujudkan tujuan yang sudah ditetapkan".

Menurut Bayu Surya Ningrat (1992 :10 ) "Pemerintah adalah perbuatan atau cara urusan Pemerintah Misalnya yang adil, Pemerintah yang demokratis, pemerintah yang dictator."

\subsection{Partisipasi Masyarakat}

Partisipasi adalah "keterlibatan mental dan emosional. Partisipasi aktual adalah gejala demokrasi di mana orang berpartisipasi dalam perencanaan dan dalam pelaksanaan dan juga memikul tanggung jawab sesuai dengan tingkat kematangan dan tingkat kewajibannya. Partisipasi itu menjadi baik di bidang baik fisik dan mental sebagai penentuan kebijaksanaan."

Menurut Slamet (dalam Suryono 2001:124) "partisipasi masyarakat dalam pembangunan diartikan sebagai ikut sertanya masyarakat dalam pembangunan, ikut dalam kegiatan pembangunan dan ikut serta memanfaatkan dan ikut menikmati hasil-hasil pembangunan."

Menurut Sajogyo (artikel :2002), "Partisipasi adalah proses dimana sejumlah pelaku telah bermitra pengaruh dan kontrol berbagi dalam inisiatif "pembangunan", termasuk membuat keputusan tentang sumber daya."

Partisipasi masyarakat menurut Isbandi (2007: 27) "adalah keikutsertaan masyarakat dalam proses pengidentifikasian masalah dan potensi yang ada di masyarakat, pemilihan dan 
pengambilan keputusan tentang alternatif solusi untuk menangani masalah, pelaksanaan upaya mengatasi masalah, dan keterlibatan masyarakat dalam proses mengevaluasi perubahan yang terjadi."

H.A.R. Tilaar ( 2009: 287) "mengungkapkan partisipasi adalah sebagai wujud dari keinginan untuk mengembangkan Demokrasi melalui proses desentralisasidimana diupayan antara lain perlunya perencanaan dari bawah (button- up) dengan mengikutsertakan masyarakat dalam proses perencanaan dan pembangunan masyarakatnya."

Jadi dari beberapa pengertian diatas, "dapat disimpulkan bahwa partisipasi adalah keterlibatan peserta secara mental, emosional dan fisik dalam menanggapi dan melaksanakan kegiatan dalam proses pembelajaran dan untuk mendukung pencapaian tujuan dan mengambil tanggung jawab atas keterlibatannya."

\subsection{Pembangunan dan Pembangunan Desa}

Pembangunan sebagai suatu perubahan, mewujudkan suatu kondisi kehidupan bernegara dan bermasyarakat yang lebih baik dari kondisi sekarang, sedangkan pembangunan sebagai suatu pertumbuhan menunjukkan kemampuan suatu kelompok untuk terus berkembang, baik secara kualitatif maupun kuantitatif dan merupakan sesuatu yang mutlak harus terjadi dalam pembangunan."

Menurut Katz dalam Yuwono (2001:47) "mengatakan pembangunan sebagai perubahan sosial yang besar dari suatu keadaan tertentu ke keadaan yang dipandang lebih bernilai. Maka untuk mencapai pembangunan nasional yang berkeadilan itu, sebagai usaha yang telah dilakukan pemerintah."

Siagian dalam Khairuddin (2000) "pembangunan merupakan usaha yang dilakukan untuk menuju suatu keadaan yang lebih baik di masa yang akan datang. Pada tataran sebuah negara, maka pembangunan merupakan upaya yang dilaksanakan untuk membawa rakyat kepada keadaan yang lebih maju, sejahtera dan mandiri."

Sumodiningrat (2001) "pembangunan adalah suatu usaha atau rangkayan usaha pertumbuhan dan perubahan yang berencanayang dilakukan secara sadar oleh suatu bangsa, negara dan pemerintah menuju modernitas dalam rangka pembinaan bangsa."

Undang-undang Nomor 6 Tahun 2014 Tentang pembangunan desa dan pembangunan kawasan Pedesaan Bagian Kesatu Pembangunan Desa Pasal 78 :

1. Pembangunan Desa bertujuan meningkatkan kesejahteraan masyarakat Desa dan kualitas hidup manusia serta penanggulangan kemiskinan melalui pemenuhan kebutuhan dasar, pembangunan sarana dan prasarana Desa, pengembangan potensi ekonomi lokal, serta pemanfaatan sumber daya alam dan lingkungan secara berkelanjutan.

2. Pembangunan Desa meliputi tahap perencanaan, pelaksanaan, dan pengawasan.

3. Pembangunan Desa sebagaimana dimaksud pada ayat (2) mengedepankan kebersamaan, kekeluargaan, dan kegotongroyongan guna mewujudkan pengarusutamaan perdamaian dan keadilan sosial.

Menurut Siagian (2005:9) pembangunan adalah "suatu usaha pertumbuhan dan perubahan yang berencana dan dilakukan secara sadar oleh suatu bangsa, negara, dan pemerintah menuju modernitas dalam rangka pembinaan bangsa". Pada dasarnya dalam negara berkembang yang lepas landas dari suatu keadaan taraf rendah menuju taraf yang tinggi yaitu modernisasi, dimana variable-variabel dalam pembangunan dapat mengalami perubahan kearah yang lebih baik. Oleh sebab itu dibutuhkan inisiatif, aktif, dan kritis bagi setiap warga negaranya untuk dapat bertindak dengan arah yang tepat dan dengan mampu menjadikan sumber-sumber dalam pembuatan keputusan oleh pemerintah dalam pembangunan.

\section{Metode Penelitian}




\subsection{Jenis Penelitian}

Pada penelitian ini penulis menggunakan jenis penelitian deskriptif kualitatif.

\subsection{Tekhnik Analisis Data}

Analisis menggunakan model analisis interaktif teori Miles dan Huberman (1994), yakni reduksi data, tampilan data, kesimpulan: gambaran dan verifikasi.

\section{Profil Desa Ngayau}

Tahun 1912 pada Jabatan Singa Deweu adalah mulainya tahun pembentukan desa yang diawali dengan mencari tempat pemukiman atau yang dulunya yang disebut Benua yang berada di Sungai Gelombang dan Daerah Sungai Tuwiq, Pemukiman yang sudah mulai teratur dan rapi maka Singa Deweu memutuskan untuk memberikan nama Benua ngayan yang artinya kampung yang pertama dibangun oleh orang banyak yang dikemudian hari diubah menjadi Desa Ngayau. Desa Ngayau memiliki jumlah Rukun Tetangga (RT) sebanyak 8 yang terorganisir, memiliki luas $3430 \mathrm{Ha}$.

Jumlah penduduk di Desa Ngayau sebanyak 1236 jiwa dengan komposisi menurut jenis kelamin adalah sebagai berikut laki-laki sebanyak 646 jiwa dan perempuan sebanyak 590 jiwa (data saat penelitian). Sedangkan jumlah kepala keluarga 371 KK (profil Desa Ngayau, 2016).

Mata pencaharian sebagai petani merupakan jumlah mata pencaharian yang palang besar dan yang paling kecil adalah yang bermatapencaharian sebagai Pegawai Negeri Sipil yaitu berjumlah 14 orang atau hanya 2,84 dari jumlah penduduk yang bekerja.

Desa Ngayau merupakan salah satu Desa di Kecamatan Muara Bengkal yang merupakan salah satu Kecamatan yang ada di Kabupaten Kutai Timur dengan luas Kecamatan 181.871.30 Km2, dengan jumlah penduduk \pm 14.025 Jiwa, Jumlah instansi vertikal Kecamatan Muara Bengkal ada 3 instansi yaitu Polsek Muara Bengkal, Koramil Muara Bengkal, dan KUA Muara.

\section{Upaya Pemerintah Desa Mendorong Partisipasi Masyarakat Dalam MembangunDesa}

\subsection{Pembinaan kepada masyarakat}

Dalam melakukan pembinaan Pemerintah Desa, BPD, Tokoh Agama, Tokoh Pemuda dan LPM saling berkoordinasi untuk melakukan pembinaan terhadap masyarakat agar menjadi masyarakat yang lebih baik.

\subsection{Pembangunan melibatkan masayarakat}

Strategi dasar yang dilakukan dalam pembuatan kebijakan adalah pembangunan yang diarahkan seminimal mungkin agar tidak terjadinya kesenjangan antara lain dengan mengurangi jumlah pengangguran yang ada selain strategi dasar tersebut maka perlu adanya strategi pendukung dalam mengatasi masalah pembangunan desa yaitu dengan pembangunan infrastruktur serta pelibatan masyarakat dalam pembangunan.

Pemerintah Desa Ngayau dan lembaga yang terkait termasuk masyarakat sebagai yang menjalankan roda pembangunan di Desa Ngayau yang bertujuan menciptakan suatu keadaan yang lebih baik dimasa yang akan datang. Makapembanguan merupakan upaya yang dilakukan untuk membawa masyarakat kepada keadaan yang lebih maju, sejahtera dan mandiri.

Pemerinta Desa melalui kerja sama dengan lembanga, tokoh-tokoh dan masyarakat untuk ikut serta dalam pembangunan yang dilakukan secara gotong royong untuk membangun infrastuktur yang ada di Desa Ngayau, Tujuannya agar masayarakat bisa sebagai pengontol kualitas pembangunan dan terlibat langsung dalam pembangunan Desa. 


\subsection{Partisipasi Masyarakat melalui Musrenbang Desa}

Musrenbang desa adalah suatu forum musyawarah yang diselenggarakan oleh lembaga publik yaitu pemerintah desa bekerjasama dengan warga dan para pemangku kepentingan untuk menyepakati rencana kegiatan untuk tahun anggaran yang nantinya akan direncanakan, dengan mengacu pada rencana pembangunan jangka menengah desa (RPJM Desa) yang sudah disusun.

Pemerintah desa ngayau tidak melibatkan masyarakat secara langsung didalam musyawarah perencanaan pembangunan maka kurangnya informasi masayarakat terhadap prioritas pembangun yang ada di Desa Ngayau, persoalan ini juga mengakibatkan kurangnya rasa kepercayaan masyarakat terhadap pemerintahan Desa.

Jadi dengan kurangnya pelibatan masyarakat secara langsung, pemerintah desa tidak melakukan fungsi dan tugasnya secara baik, akibatnya adalah pemerintah desa mendapat sangsi sosial dan tanggapan negatif dari masyarakat.

8.4. Masyarakat dalam pelestarian kesenian tradisional

Dalam melestarian kesenian tradisional, Pemerintah Desa Ngayau mengadakan kerja sama dengan Tokoh dan lembanga-lembang yang ada khususnya lembanga adat, karena lembaga adat adalah lembaga yang berkontribusi untuk melestarikan kesenian tradisional.

Sehingga pemerintah Desa melalui kerja sama dengan Tokoh Adat dan Lembaga lainnya sudah baik mengajak masyarakat dalam mengembangakan dan mempertahankan kesenian tradisional, namun masih banyak masayarakat yang belum mengetahui pentingnya pelestarian kesenian tradisional.

\subsection{Faktor Pendukung}

Faktor pendukung dan sekaligus faktor kekuatan upaya pemerintah Desamendorong partisipasi masyarakat dalam membangun Desa adalah hal ini disebutkan dalam Undangundang Nomor 6 Tahun 2014 tentang Desa, pemerintah Desa diberikan kewenang penuh untuk mengurus pemerintahan Desa.

\subsection{Faktor Penghambat}

Faktor yang menghambat upaya pemerintah Desa dalam mendorong partisipasi masyarakat dalam membangun Desa, yakni pendidikan yang masih rendah, hal ini mengakibatkan tingkat pemahaman masayarakat terhadap proses pembangunan menjadi minim, Sarana dan Prasarana, faktor ini merupakan pendukung bagi terselenggaranya aktifitas Pemerintah Desa. Sarana dan Prasarana yang harus cukup memadai baik dari segi jumlahnya, dari segi ku alitasnya dan praktis dari segi penggunaannya, syarat-syarat sarana dan prasarana semacam ini lah yangakan sangat berpengaruh terhadap penyelenggaraan Pemerintah Desa, Keuangan, faktor ini adalah tulang punggung bagi terselenggaranya aktifitas Pemerintah Desa. Salah satunya ciri dari daerah otonom adalah terletak pada kemampuan dalam bidang keuangan. Karena itu kemampuan keuangan ini akan sangat memberikan pengaruh terhadap penyelenggaraan Pemerintah Desa.

\section{Kesimpulan}

9.1. Kegiatan pembinaaan kepada masyarakat yang meliputi pengendalian kebakaran hutan, majelistalim, dan pemantawan jentik nyamuk pemerintah desa bekerja sama dengan lembaga dan tokoh-tokoh yang ada di desa Ngayau, namun kegiatan pembinaan belum berjalan dengan baik dan optimal. 
9.2. Kegiatan pembangunan melibatkan masayarakat, pemerintah bekerja sama dengan lembanga dan tokoh-tokoh untuk mengajak masayarakat dalam gotong-royong membangun pasilitas infrastuktur sudah berjalan baik.

9.3. Kegiatan musrenbang melibatkan masyarakat, pemerintah desa sangat lah kurang melibatkan masyarakat didalam kegiatan musrenbang.

9.4. Pelestarian kesenian tradisional, Pemerintah Desa melalui kerja sama dengan tokoh adat dan lembaga lainya sudah sangat baik mengajak masayarakat dalam mengembangkan dan mempertahankan kesenian tradisional, namun masih banyak masayarakat yang belum mengetahui pentingnya pelestarian pelestarian kesenian tradisional.

9.5. Faktor pendukung dan sekaligus faktor kekuatan upaya pemerintah Desa mendorong partisipasi masyarakat dalam membangun Desa adalahhal ini disebutkan dalam Undangundang Nomor 6 Tahun 2014 tentang Desa, pemerintah Desa diberikan kewenang penuh untuk mengurus pemerintahan Desa.

9.6. Faktor yang menghambat upaya pemerintah Desa dalam mendorong partisipasi masyarakat dalam membangun Desa, yakni pendidikan yang masih rendah, hal ini mengakibatkan tingkat pemahaman masayarakat terhadap proses pembangunan menjadi minim, Sarana dan Prasarana.

10.Daftar Pustaka

ANONIM, Undang-undang Dasar Negara Republik Indonesia Tahun 1945.

----------- , Undang-undang Nomor 6 Tahun 2014 Tentang Pemerintah Desa

---------- , Undang-undangNomor 23 Tahun 2014 Tentang Pemerintah Daerah

Agus Suryono. 2001. Teori dan Isi Pembangunan. Malang: Universitas Negeri Malang.UM Press.

Bintoro Tjokroamidjojo.1995. Pengantar Administrasi Pembangunan. LP3S. Jakarta

Bayu Surya Ningrat. 1992. Perencanaan Pembangunan Daerah. PT. GramediaPustakaUtama. Jakarta

Dedi Mulyono, 2001. Perencanaan Dan Pengendalian Program Pembangunan. Universitas Indonesia Press. Jakarta

Deddy T. Tikson. 2005. Indikator-indikator Pembangunan Ekonomi.

HAR Tilar 2009 Kekuasaan dan Pendidikan : Kajian Manajemen Pendidikan Nasional Dalam Pusaran Kekuasaan. Jakarta : Rinika Cipta

Iqbal Hasan, 2004. AnalisisPenelitianDenganStatistik. PT, BimaAksa, Jakarta

Isbandi Rukminto Adi. (2007). Perencanaan Partisipatoris Berbasis Aset Komunitas: dari Pemikiran Menuju Penerapan. Depok: FISIP UI Press

Khairudin, SS. (2000). Pembangunan Masyarakat Tinjauan aspek: sosiologi, ekonomi dan perencanaan. Yogyakarta : Penerbit Liberti Yogyakarta.

Kaelen, 2015. Metodologi Penelitian Kualitatif Bidang Filsafat, Yogyakarta Paradigma.

Lexi J. Meleong, 2002. Metodelogi Penelitian Kualitatif. Bandung: Remaja Rosdakarya jakarta.

---------- 2004 Metodelogi Penelitian Kualitatif. Bandung: Remaja Rosdakarya

Miles, Matthew. B. dan A. Michael Huberman. 2007. Analisis Data Kualitatif. Jakarta: Universitas Indonesia.

Moh. Kusnardi dan Bintan R. Saragih. 2008. Ilmu Negara. Jakarta: Gaya Media Pratama.

Poerwadarminta W.J.S, (1991), Kamus Umum Bahasa Indonesia, Balai Pustaka, Jakarta.

Profil Desa Ngayau 2016 Sejarah Desa Ngayau Kecamatan Muara Bengkal Kabupaten Kutai Timur. Kantor Desa Ngayau.

Sumodiningrat G. 2001. Menuju Swasembada Pangan Revolusi Hijau. Jakarta: RBI.

Sugiyono 2001. Metode Penelitian Administrasi. Bandung: Alfabeta

----- , 2006. Metode Penelitian Administrasi. Bandung: Alfabeta

----------- , 2009. Metode Penelitian Administrasi, Edisi Revisi, Cetakan XVII. Bandung :Alfabeta 
2012. Metode Penelitian Pendidikan Pendekatan Kuantitatif Kualitatif,dan R\&D. Bandung: ALFABETA. 2012 (cet. 15)

Sajogyo Pudjiwati. 2002. Sosiologi Pedesaan : Kumpulan Bacaan, Yogyakarta Gajah Mada University Press

Sutisno Hadi, 2004, Metodologi Research Jilid I, Penerbit Andi Offset, Yogyakarta.

Sondang. P Siagian. 2005. Administrasi Pembangunan, Konsep Dimensi dan Strateginya. Jakarta: Bumi Aksara.

Tim Penyusun Departemen Pendidikan Nasional. 2008. Kamus Besar Bahasa Indonesia. Jakarta:Balai Pustaka.

Yuwono, 2001. Manajemen Otonomi Daerah :Membangun Daerah Berdasarkan Paradigma Baru. Semarang: Ciyapps Diponegoro Universiti 